\title{
Plant extracts, metaldehyde and saline solutions on the population control of Bradybaena similaris
}

\author{
Extratos vegetais, metaldeído e soluções salinas para \\ o controle populacional de Bradybaena similaris
}

\author{
Junir Antonio Lutinski ${ }^{\mathrm{I}^{*}}$ Fernanda Piovesan Bonfante $^{\mathrm{II}}$ \\ Maria Assunta Busato ${ }^{I}$ Carin Guarda ${ }^{I}$
}

\section{ABSTRACT}

This study aimed to test the efficiency of plant extracts, metaldehyde and saline solutions, as alternatives to the population control of the snail Bradybaena similaris, and to investigate the effect of the plant extracts in reducing the damage of the snail on Brassica oleracea. The experiments were performed at the Entomology Laboratory of the Universidade Comunitária da Região de Chapecó (Unochapecó), using a random experimental design with nine treatments in triplicate. Five adult individuals of B. similaris were subjected to each trial, totaling 135 snails. The following treatments were tested: cinnamon (Melia azedarach), timbó (Ateleia glazioveana), rosemary (Rosmarinus officinalis), mate herb (Ilex paraguariensis), two concentrations of metaldehyde (3\% and 5\%), two concentrations of salt solution $(5 \%$ and $10 \%$ ), and a control treatment (distilled water). To evaluate the survival of $\boldsymbol{B}$. similaris it was checked the treatments every 24 hours, over four consecutive days. The results revealed that the two concentrations of metaldehyde were fully efficient, that the saline solution (10\%) had and intermediate efficiency, and that all other treatments were not effective. The treatment with the M. azedarach extract induced a higher consumption of $\boldsymbol{B}$. oleracea, while the saline solution at $10 \%$ and the extracts of $\boldsymbol{R}$. officinalis and $\boldsymbol{I}$. paraguariensis inhibited leaf consumption.

Key words: rosemary, Ateleia glazioveana, cinnamon, mate herb, molluscicide.

\section{RESUMO}

O objetivo deste trabalho foi avaliar a eficiencia de extratos vegetais, metaldeido e soluções salinas como alternativas para o controle populacional de Bradybaena similaris e o efeito dos extratos para a redução dos danos sobre Brassica oleracea, em condições de laboratório (Laboratório de Entomologia da Unochapecó, Chapecó, Santa Catarina). O experimento foi conduzido utilizando cinco individuos adultos de B. similares para cada um dos nove tratamentos em triplicatas, totalizando 135 caracóis. Os seguintes tratamentos foram testados: extrato de cinamomo (Melia azedarach), timbó (Ateleia glazioveana), alecrim (Rosmarinus officinalis), erva-mate (Ilexparaguariensis), metaldeido (3\% e 5\%), soluções salinas (5\% e 10\%) e a testemunha (água destilada). Para avaliação dos dados, foi determinada a taxa de sobrevivência de B. similaris a cada 24 horas em um periodo de quatro dias. Os resultados obtidos indicam que as duas concentrações de metaldeído foram eficientes, a solução salina (10\%) apresentou eficiência intermediária, enquanto os demais tratamentos não foram eficazes. Observou-se que o tratamento com extrato de $\boldsymbol{M}$. azedarach induziu a um consumo maior de $\boldsymbol{B}$. oleracea, enquanto a solução salina a $10 \%$ e os extratos de $\boldsymbol{R}$. officinalis e I. paraguariensis inibiram o consumo.

Palavras-chave: alecrim, Ateleia glazioveana, cinamomo, ervamate, moluscicida.

\section{INTRODUCTION}

Slugs and snails (terrestrial gastropods) are amongst the major agricultural pests because they are capable to attack different cultures, both in conventional and organic crops. The damage caused by mollusks has increased due to the introduction of new crops, expansion of cultivated areas, and the spread of exotic species (BARONIO et al., 2014). Due to the recent growing of organic farming (ABREU et al., 2012), there has been an increased interest for searching natural products that can help to control

\footnotetext{
'Programa de Pós-graduação em Ciências da Saúde (PPGCS), Universidade Comunitária da Região de Chapecó (Unochapecó), Av. Senador Attílio Fontana, 591-E, CP 1141, Efapi, 89809-000, Chapecó, SC, Brasil. E-mail: junir@unochapeco.edu.br. "Corresponding author.

IIEspecialização em Licenciamento Ambiental, Universidade Regional Integrada do Alto Uruguai e das Missões (URI), Frederico Westphalen, RS, Brasil. 
populations of these species. The snail Bradybaena similaris (Fèrussac, 1821) is a pulmonate, terrestrial gastropod, popularly known as "garden snail". It is very common in urban and peri-urban areas, and it is often observed during rainy periods in vegetable crops, gardens, and ornamental potted plants (THIENGO et al., 2005). It is considered a pest of cultivated plants (ARAÚJO, 1989) and stands out among the mollusks of economic and parasitological interest, for consuming vegetables and ornamental plants, and because it can transmit worm eggs, bacteria, protozoa and fungi related to human diseases (JUNQUEIRA et al., 2008). Of asian origin, this species was introduced in tropical regions by the plant trade (ARAÚJO, 1989). It currently occurs in north, central and south america, and in Brazil it is distributed from Amapá to Rio Grande do Sul, with well-established populations in man-made environments (ARAÚJO, 1989; THIENGO et al., 2005).

Population control of terrestrial mollusks should include the correct recognition of the target species, manual capture of individuals, and their subsequent elimination (GARCIA, 2002). Use of synthetic products should be evaluated with caution, because such products can contaminate the soil and the water, and may consequently affect local populations of humans and other animals (THIENGO et al., 2005). In fact, these products have their application prohibited to organic farming. Therefore, the use of natural products, which are selective and biodegradable, represents an appropriate alternative for controlling populations of mollusks (VENDRAMIM \& CASTIGLIONI, 2000; FERREIRA et al., 2010). Indiscriminate use of synthetic products can result in adverse effects on human health, depending on the form, time of exposure, type of product, and its specific toxicity (TRAPÉ, 1994). Brazil is ranked as one of the world's biggest consumers of pesticides; in horticulture, for instance, the average annual consumption of pesticides can exceed $10 \mathrm{~kg}$ per hectare (PERES \& MOREIRA, 2007).

Given the above, this study aimed 1) to evaluate the efficiency of natural products and saline solutions on the population control of $\boldsymbol{B}$. similaris, comparing the efficiency of these products with metaldehyde-based commercial formulations, and 2) to evaluate the repellency potential of plant extracts on B. similaris.

\section{MATERIALS AND METHODS}

This experimental study was conducted at the Entomology Laboratory of the Universidade
Comunitária da Região de Chapecó (Unochapecó), Chapecó, Santa Catarina, Brazil. It was used a randomized experimental design, including nine treatments in triplicate. Bioassays were performed under controlled conditions of temperature $\left(27^{\circ} \mathrm{C}\right.$ to $30^{\circ} \mathrm{C}$ ) and photoperiod (12 hours).

\section{Treatments}

The following treatments were tested: I) aqueous extract of cinnamon (Melia azedarach L.), II) aqueous extract of timbó (Ataleia glazioveana Bail.), III) aqueous extract of rosemary (Rosmarinus officinalis L.), IV) aqueous extract of mate herb (Ilex paraguariensis St. Hil.), two synthetic products with metaldehyde-based active principle (Madelesma ${ }^{\circledR}$ and Metare $^{\circledR}$ ) embedded in toxic bait pellets with $V$ ) $3 \%$ concentration and VI) 5\% concentration, and saline solution at the concentrations of VII) $5 \%$ and VIII) $10 \%$.

Plant extracts were obtained from fresh leaves of plants collected in the city of Frederico Westphalen, Rio Grande do Sul, Brazil (27 21' $27^{\prime \prime}$ S, $53^{\circ} 23^{\prime} 40^{\prime}$ ' W). In the laboratory, 50 grams of leaves were macerated and submerged in a volume of 100 $\mathrm{ml}$ of distilled water, and were subsequently put for resting during 48 hours. This procedure was made for all plant extracts. For the saline solutions it was used $5 \mathrm{~g}$ and $10 \mathrm{~g}$ of the commercial form of sodium chloride $(\mathrm{NaCl})$, which was dissolved in $100 \mathrm{ml}$ of distilled water. As for the metaldehyde, it was used $1 \mathrm{~g}$ of each concentration of the commercial products. As a control treatment it was used only distilled water and food.

All specimens of $\boldsymbol{B}$. similaris were collected on December 08, 2014, in a rural property at the Matias do Bem locality $\left(27^{\circ} 39^{\prime} 26^{\prime \prime} \mathrm{S}, 53^{\circ} 19^{\prime}\right.$ 8 " W), located in the municipality of Boa Vista das Missões, Rio Grande do Sul. Collection was carried out between $20 \mathrm{~h}$ and $23 \mathrm{~h}$, in a cabbage plantation (Brassica oleracea Linnaeus) of a family vegetable garden. The specimens of $\boldsymbol{B}$. similaris were manually captured using latex gloves, and then packed into a polyethylene box for transportation to the Entomology Laboratory of Unochapecó.

Each experimental unit consisted in a polyethylene arena of $10 \mathrm{~cm}$ in diameter and $11 \mathrm{~cm}$ in depth. For all treatments it was used only undrilled, young leaves of cabbage (B. oleracea). Leaves were immersed in the aqueous extract or in the saline solution for approximately five seconds, without using any adhesive substance, and were subsequently accommodated in the arenas. The arenas were closed with a porous nylon tissue, thus allowing for ventilation. In each arena it was placed five adult specimens of $\boldsymbol{B}$. similaris (upper shell dimension: 
$8 \mathrm{~mm}$ high, $14 \mathrm{~mm}$ wide), totaling 135 snails. For all treatments, five spraying of distilled water were given every 24 hours interval.

Data analysis

To evaluate the survival of $\boldsymbol{B}$. similaris specimens, it was checked the treatments every 24 hours, over four consecutive days. At the end of a 96 hours period, the leaves of $\boldsymbol{B}$. oleracea were removed, and their consumed areas were measured in $\mathrm{cm}^{2}$ using a caliper. To test the efficiency of each treatment it was used the formula proposed by ABBOTT (1925). It was performed an analysis of variance (ANOVA) based on the number of live snails and the leaf area of $\boldsymbol{B}$. oleracea consumed. This test allowed for comparing the averages among treatments at intervals of 24 hours, and the intake of leaves of each treatment after 96 hours. Data frequencies were previously transformed into $\log (\mathrm{x}+1)$. Means were grouped and compared by the Duncan test, at $5 \%$ probability of error.

\section{RESULTS}

There were significant differences between the food treatments containing the extracts and the control treatment, with regards to the mean survival of B. similaris $(\mathrm{F}=372.6, \mathrm{P}<0.01)$ as well as to the time of exposure $(\mathrm{F}=7.82 ; \mathrm{P}<0.01)$. The coefficient of variation between the averages of different treatments was $9.2 \%$.

The two concentrations of metaldehyde (3\% and 5\%) presented the greatest reduction of $\boldsymbol{B}$. similaris, reaching a mortality of $100 \%(\mathrm{~N}=5)$, and significantly differed from the control and other treatments. The treatment with the saline solution at $10 \%$ showed an intermediate efficiency $(42 \%$, $\mathrm{N}=2.09$ ), and had a significant difference as compared to the other treatments (Figure 1). Conversely, all the aqueous extracts and the saline solution at $5 \%$ did not differ from the control treatment (Table 1).

The extract of A. glazioviana and the 5\% saline solution did not differ from the control treatment with regards to the consumed leaf area of B. oleracea. For the treatment with M. azerdarach, in turn, there was a significantly higher consumption, whilst the leaf consumption was lower in the treatments with the saline solution at $10 \%$ and with the extracts of $\boldsymbol{R}$. officinalis and I. paraguariensis (Figure 2).

\section{DISCUSSION}

The snail $\boldsymbol{B}$. similaris did not present any susceptibility to the tested natural extracts, while the synthetic, metaldehyde-based commercial products were totally efficient and caused the mortality of all specimens in 48 hours. The brine recommended by GARCIA (2002) showed a repellent effect on $\boldsymbol{B}$. similaris at the concentration of $10 \%$, as well as did the extracts of $\boldsymbol{R}$. officinalis and $\boldsymbol{I}$. paraguariensis. The effect of natural products on invertebrate organisms is quite variable, which may be toxic, repellent, cause sterility, modify the behavior and development, or reduce the feeding activity of the organism (ARNASON et al., 1990).

The molluscicidal efficiency of metaldehyde, in its maximum concentration allowed (5\%) by ANVISA, the Brazilian National

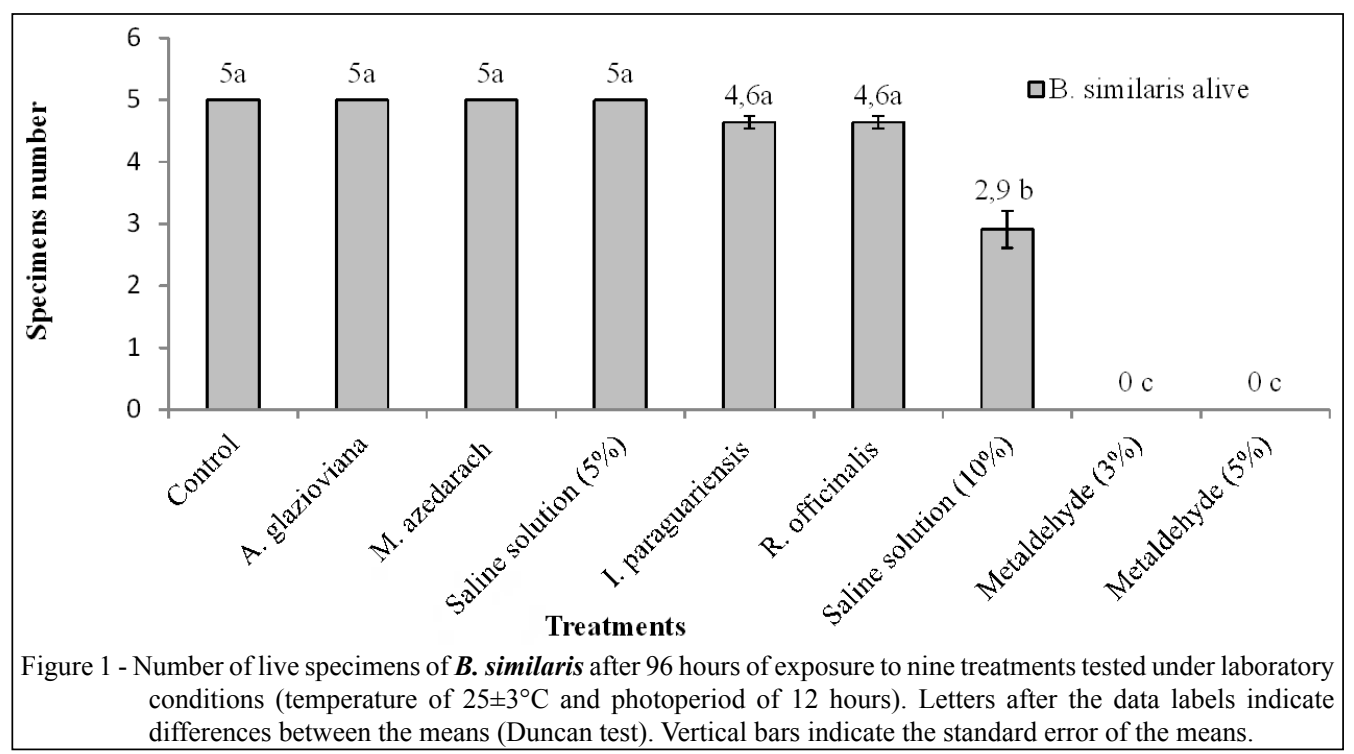

Ciência Rural, v.46, n.8, ago, 2016. 
Table 1 - Treatments, average of live specimens of $\boldsymbol{B}$. similaris after 96 hours followed by standard error, and efficiency of each treatment tested under laboratory conditions (temperature of $25 \pm 3{ }^{\circ} \mathrm{C}$ and photoperiod of 12 hours).

\begin{tabular}{lcc}
\hline Treatments & $\begin{array}{c}\text { Average of live } \\
\text { specimens }\end{array}$ & Efficiency (\%) \\
\hline Control & $5 \pm 0$ & 0.0 \\
A. glazioviana (Timbó) & $5 \pm 0$ & 0.0 \\
M. azedarach (Cinnamon) & $5 \pm 0$ & 0.0 \\
Saline solution (5\%) & $5 \pm 0$ & 0.0 \\
I. paraguariensis (Mate herb) & $4.6 \pm 0.1$ & 7.0 \\
R. officinalis (Rosemary) & $4.6 \pm 0.1$ & 7.0 \\
Saline solution (10\%) & $2.9 \pm 0.3$ & 42.0 \\
Metaldehyde (3\%) & $0 \pm 0$ & 100.0 \\
Metaldehyde (5\%) & $0 \pm 0$ & 100.0 \\
\hline
\end{tabular}

Health Surveillance Agency (BRASIL, 2007), was recently tested by BARONIO et al. (2014). These authors have reported a mortality rate of $15 \%$ on the slug Meghimatium pictum (Stoliczka 1873) under laboratory conditions. Efficiency of $100 \%$ of metaldehyde at a $3 \%$ concentration for the control of $\boldsymbol{B}$. similaris, as observed in the present study, indicates that the susceptibility of slugs and snails to this product varies among species.

Pioneering studies on natural products with molluscicidal effect have demonstrated the efficiency of the extracts of Serjania spp. and Sapindus saponaria L. on Biomphalaria glabrata Say, 1818, resulting from the action of the saponins of these plants (SILVA et al., 2008). Meliaceae plants are used in ecologically-based production systems, and their use has been highlighted in studies about pest population control. Plant species such as the neem (Azadirachta indica A. Juss) and the cinnamon (M. azedarach) are known to have broad activity on other plants, insects and pathogens. The main metabolites of these plants are the azadirachtin and the melianona (ROSSI et al., 2007). The oil from M. azedarach was successfully tested as an inhibitor of the larval development of Spodoptera frugiperda (Smith, 1797) (Lepidoptera) (SCAPINELLO et al., 2014). Nevertheless, in this study the pure extract of M. azedarach did not present any molluscicidal activity on $\boldsymbol{B}$. similaris.

Insecticidal activity of the extracts of $\boldsymbol{A}$. glazioviana was reported by MIGLIORINI et al. (2010), who reported an efficiency of over $80 \%$ for the control of Diabrotica speciosa (Coleoptera), and by GERHARDT et al. (2012), who reported the extracts to be efficient on Myzus persicae (Sulzer, 1776) (Hemiptera) and Ascia monuste orseis (Linnaeus, 1764) (Lepidoptera). Rotenone is one of the main metabolites present in the extracts of A. glazioviana (SAITO \& LUCHINI, 1998). In the present study; however, it was not observed any molluscicidal or repellent activity of the aqueous extract of $\boldsymbol{A}$. glazioviana on B. similaris.

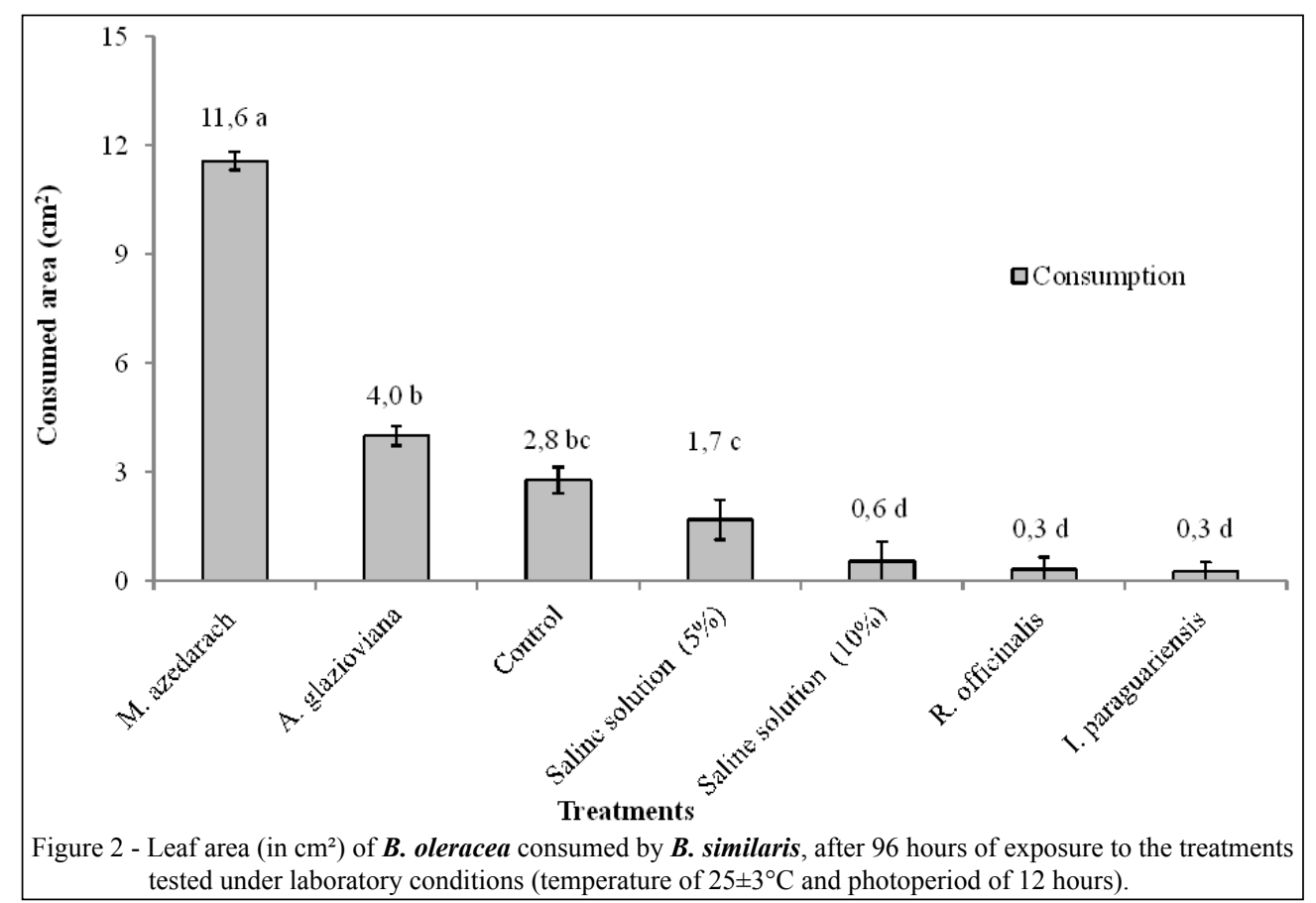

Ciência Rural, v.46, n.8, ago, 2016. 
Compounds predominantly found in the extracts of $\boldsymbol{R}$. officinalis (rosemary) are $\alpha$-pyrene, $\beta$-myrcene, camphor, eucalyptol (OZAROWSKI et al., 2013) and terpenes. Studies about $\boldsymbol{R}$. officinalis have shown its insecticide and acaricide (MARTINEZ-VELASQUEZ et al., 2011) potential. It was reported that the snail B. similaris did not present any susceptibility to the aqueous extract of rosemary, although the consumption of $\boldsymbol{B}$. oleracea was lower in the treatment with the extract of rosemary, which indicated some degree of repellency.

Leaves and branches of I. paraguariensis (mate herb) are used for the production of beverages like tea and mate (MACCARI \& SANTOS, 2000). The insecticidal potential of this plant was tested by BUSATO et al. (2015), who have reported a larvicidal efficiency on Aedes aegypti (Linnaeus, 1762), reaching $100 \%$ of mortality at the concentration of $2000 \mu \mathrm{g} \mathrm{ml}^{-1}$. Amongst the major metabolites reported in I. paraguariensis are alkaloids such as caffeine and theobromine (GNOATTO et al., 2007), which may be responsible for limiting the consumption of cabbage leaves by $\boldsymbol{B}$. similaris. FERREIRA et al. (2010) tested two concentrations of caffeine $\left(2 \mathrm{~g} \mathrm{~L}^{-1}\right.$ and $\left.5 \mathrm{~g} \mathrm{~L}^{-1}\right)$ in the control of $\boldsymbol{B}$. similaris, and reported efficiency at the concentration of $5 \mathrm{~g} \mathrm{~L}^{-1}$.

According to VENDRAMIM \& CASTIGLIONI (2000), studies with natural products should be encouraged because these products impose little or none environmental impact, are more selective, do not leave residues in foods, and because the development of pest resistance to natural products is unknown. Hence, natural products well known by people, such as the brine (GARCIA, 2002), may represent a suitable alternative to reduce the damage caused by the snail $\boldsymbol{B}$. similaris.

\section{CONCLUSION}

We concluded that: 1) Trials with the aqueous extracts indicated that plant extracts were not completely effective. 2) Treatment with the extracts of M. azedarach had the opposite effect, leading to higher consumption of leaves in comparison to the control treatment. 3) Extract of A. glasioveana and the saline solution at $5 \%$ had no molluscicidal, inhibitor or repellent effects, showing no difference from the control treatment with regards to the consumed leaf area of B. oleracea. 4) Extracts of $\boldsymbol{R}$. officinalis and $\boldsymbol{I}$. paraguariensis inhibited the consumption of leaves of B. oleracea, suggesting the existence of metabolites capable of limiting the consumption of leaves; this result opens up possibilities for further testing isolated compounds of these plants. 5) metaldehyde was $100 \%$ effective at the two tested concentrations (5\% and $3 \%$ ), inducing the mortality of all snails. 6) 1 Lower concentration of metaldehyde tested (3\%) is below the maximum concentration allowed by ANVISA; thus, it is suggested that a lower degree of this molluscicidal active principle should be used in some cases, ensuring its efficiency and reducing potential environmental impacts.

\section{REFERENCES}

ABBOTT, W.S. A method of computing the effectiveness of an insecticide. Journal of Economic Entomology, v.18, p.265267, 1925. Available from: <http://jee.oxfordjournals.org/ content/18/2/265.2>. Accessed: Mar. 16, 2016.

ABREU, L.S. de et al. Relations Between Organic Agriculture and Agroecology: Current Challenges Around the Principles of Agroecology. Desenvolvimento e Meio Ambiente, Editora UFPR, v.26, p.143-160, 2012. Available from: <https://www.google.com. br/?gws_rd $=$ ssl\#q $=$ Rela $\% \mathrm{C} 3 \% \mathrm{~A} 7 \% \mathrm{C} 3 \% \mathrm{~B} 5 \mathrm{es}+$ entre + agricultura $+\mathrm{o}$ $\mathrm{rg} \% \mathrm{C} 3 \% \mathrm{~A} 2$ nica+e+agroecologia:+desafios+atuais+em+torno+dos + princ\% $\%$ C3\%ADpios+da+agroecologia $>$. Accessed: Set. 20, 2015.

ARAÚJO, J.L.B. Moluscos de importância no Brasil. Xanthonychidae: Bradybaena similaris (Férussac, 1821). (Mollusca, Gastropoda, Pulmonata, Stylommatophora). Revista Brasileira de Zoologia, v.6, n.4, p.583-592,1989. Available from: <http://www.scielo.br/scielo.php?pid=S010181751989000400001\&script $=$ sci_abstract $>$. Accessed: Mar. 17, 2016. doi: 10.1590/S0101-81751989000400001.

ARNASON, J.T. et al. Insecticide of plant origin. Washington, DC: American Chemical Society, 1990. 214p.

BARONIO, C.A. et al. First record of qualitative losses caused by Meghimatium pictum in vineyards of Southern Brazil and the effects of two molluscicides for its control. Ciência Rural, v.44, n.10, p.1715-1720, 2014. Available from: <http://www.scielo.br/ scielo.php?script $=$ sci_arttext\&pid $=\mathrm{S} 0103-84782014001001715>$. Accessed: Ago. 08, 2015. doi: 10.1590/0103-8478cr20130522.

BRASIL. Agência Nacional de Vigilância Sanitária (ANVISA). Consulta Pública n.48, de 23 de maio de 2007. Diário Oficial da União de 24/05/2007. 2007. Available from: $<$ http://www4. anvisa.gov.br/base/visadoc/CP/CP\%5B18550-1-0\%5D.PDF $>$. Accessed: Jul. 28, 2015.

BUSATO, M.A. et al. Potencial larvicida de Melia azedarach L. e Ilex paraguariensis A. St.-Hil. no controle de Aedes aegypti (Linnaeus, 1762) (Diptera: Culicidae). Ciência e Natura, v.37, n.2, p. 277-282, 2015. Available from: <http://cascavel.ufsm.br/revistas/ ojs-2.2.2/index.php/cienciaenatura/article/view/15922>. Accessed: Jul. 10, 2015. doi: 10.5902/2179460X15922

FERREIRA, P. et al. Influência da cafeína sobre a sobrevivência, crescimento e reprodução de Bradybaena similaris (Férussac, 1821) (Mollusca, Xanthonychidae), com diferentes idades. Revista Brasileira de Zoociências, v.12, n.2, p.47-53, 2010. Available from: <http://zoociencias.ufjf.emnuvens.com.br/zoociencias/article/ view/1582>. Accessed: Fev. 15, 2015.

Ciência Rural, v.46, n.8, ago, 2016. 
GARCIA, F.R.M. Zoologia agrícola: manejo ecológico de pragas Porto Alegre: Rigel, 2002. 256p.

GERHARDT, A. et al. Atividade inseticida de extratos botânicos de três espécies silvestres do Rio Grande do Sul, Brasil, sobre Myzus persicae (Hemiptera: Aphididae) e Ascia monuste orseis (Lepidoptera: Pieridae). Caderno de Pesquisa, série Biologia, v.24, n.2, p.55-64, 2012. Available from: http://online.unisc.br/seer/index php/cadpesquisa/article/view/3590/3113. Accessed: Jan. 25, 2015.

GNOATTO, S.C.B. et al. Influência do método de extração nos teores de metilxantinas em erva-mate (Ilex paraguariensis A. St.Hil., Aquifoliaceae). Química Nova, v.30, n.2, p.304-307, 2007. Available from: <http://www.scielo.br/scielo.php?script=sci_artt ext\&pid=S0100-40422007000200012>. Accessed: Jul. 10, 2015. doi: 10.1590/S0100-40422007000200012.

JUNQUEIRA, F.O. et al. Influência do substrato sobre aspectos do ciclo de vida de Bradybaena similaris (Férussac, 1821) (Mollusca, Bradybaenidae), sob condições de laboratório. Revista Brasileira de Biociências, v.6, n.4, p.347-354, 2008. Available from: <http:// www.ufrgs.br/seerbio/ojs/index.php/rbb/article/view/962>. Accessed: Jun. 12, 2015.

MACCARI, A.J.; SANTOS, A.P.R. Produtos alternativos e desenvolvimento da tecnologia industrial na cadeia produtiva da erva-mate. Curitiba: MCT/CNPq/PADCT, 2000. 160p.

MARTINEZ-VELAZQUEZ, $M$. et al. Acaricidal effect of essential oils from Lippia graveolens (Lamiales: Verbenaceae) Rosmarinus officinalis (Lamiales: Lamiaceae), and Allium sativum (Liliales: Liliaceae) against Rhipicephalus (Boophilus) microplus (Acari: Ixodidae). Journal of Medical Entomology, v.48, p.822-827, 2011. Available from: <http://www.ncbi.nlm.nih. gov/pubmed/21845941>. Accessed: Ago. 05, 2015.

MIGLIORINI, P. et al. Eficiência de extratos vegetais no controle de Diabrotica speciosa (Germar, 1824) (Coleoptera: Chrysomelidae), em laboratório. Biotemas, v.23, n.1, p.83-89, 2010. Available from: $<$ https://periodicos.ufsc.br/index.php/biotemas/article/view/21757925.2010v23n1p83>. Accessed: Set. 20, 2015.

OZAROWSKI, M. et al. Rosmarinus officinalis L. leaf extract improves memory impairment and affects acetylcholinesterase and butyrylcholinesterase activities in rat brain. Fitoterapia, v.91, p.261-271, 2013. Available from: <http://www.ncbi.nlm.nih. gov/pubmed/24080468>. Accessed: Jun. 10, 2015. doi: 10.1016/j. fitote.2013.09.012

PERES, F.; MOREIRA, J.C. Saúde e ambiente em sua relação com o consumo de agrotóxicos em um pólo agrícola do Estado do Rio de Janeiro, Brasil. Cadernos de Saúde Pública, v.23, n.4, p.612-621, 2007. Available from: $<$ http://www.scielo.br/scielo.php?script $=$ sci arttext\&pid=S0102-311X2007001600021>. Accessed: Mai. 10, 2015. doi: 10.1590/S0102-311X2007001600021.

ROSSI, J.C.N. et al. Efeito larvicida de extratos etanólicos de folhas Secas e frutos maduros de Melia azedarach (Meliaceae) sobre Aedes albopictus. Latin American Journal of Pharmacy, v.26, n.5, p.737-740, 2007. Available from: <http://www.latamjpharm.org/ resumenes/26/5/LAJOP 26_5_2_2.pdf $>$. Accessed: Jun. 25, 2015.

SAITO, M.; LUCHINI, F. Substâncias obtidas de plantas e a procura por praguicidas eficientes e seguras ao meio ambiente. Jaguariúna: Embrapa-Meio Ambiente, 1998. 46p.

SCAPINELLO, J. et al. Insecticidal and growth inhibiting action of the supercritical extracts of Melia azedarach on Spodoptera frugiperda. Revista Brasileira de Engenharia Agrícola e Ambiental, v.18, n.8, p.866-872, 2014. Available from: <http://www.scielo.br/scielo. php?script $=$ sci_arttext\&pid $=$ S1415-43662014000800014 $>$. Accessed: Set. 10, 2015. doi: 10.1590/1807-1929/agriambi.v18n08p866-872.

SILVA, N.F.S. et al. Bioensaio de atividade moluscicida adaptado para a avaliação de extratos de plantas medicinais. Arquivos de Ciências Veterinárias e Zoológia da Unipar, v.11, n.2, p.179181, 2008. Available from: <http://revistas.unipar.br/veterinaria/ article/viewFile/2575/2003>. Accessed: Abr. 21, 2015.

THIENGO, S.C. et al. Moluscos exóticos com importância médica no Brasil. Departamento de Malacologia, Instituto Oswaldo Cruz, Fundação Oswaldo Cruz, p.1-14, 2005. Available from: <http://www.mma.gov.br/estruturas/174/ arquivos/174_05122008104832.pdf>. Accessed: Mar. 10, 2016.

TRAPÉ, A.Z. O caso dos agrotóxicos. In: BUSCHINELLI, J.T.P. et al. (Orgs.). Isto é trabalho de gente? Petropólis: Vozes, 1994. p.568-593.

VENDRAMIM, J.D.; CASTIGLIONI, E. Aleloquímicos, resistência de plantas e plantas inseticidas. In: GUEDES, J.C. et al. (Orgs.). Bases e técnicas do manejo de insetos. Santa Maria: Pallotti, 2000. p.113-128. 